OPEN ACCESS

Edited by:

Karl Ljungberg,

Karolinska Institutet (KI), Sweden

Reviewed by:

Si-Yang Huang,

Yangzhou University, China

Ehsan Ahmadpour,

Tabriz University of Medical Sciences,

Mun Yik Fong,

University of Malaya, Malaysia

${ }^{*}$ Correspondence:

Hua Cong

conghua@sdu.edu.cn

Shenyi He

shenyihe@sdu.edu.cn; shenyi.he@hotmail.com

Specialty section:

This article was submitted to Vaccines and Molecular Therapeutics,

a section of the journal

Frontiers in Immunology

Received: 28 December 2018 Accepted: 05 March 2019

Published: 29 March 2019

Citation:

Guo J, Zhou A, Sun X, Sha W, Ai K,

Pan G, Zhou C, Zhou H, Cong $H$ and

He S (2019) Immunogenicity of a

Virus-Like-Particle Vaccine Containing

Multiple Antigenic Epitopes of

Toxoplasma gondii Against Acute and

Chronic Toxoplasmosis in Mice.

Front. Immunol. 10:592.

doi: 10.3389/fimmu.2019.00592

\section{Immunogenicity of a} Virus-Like-Particle Vaccine Containing Multiple Antigenic Epitopes of Toxoplasma gondii Against Acute and Chronic Toxoplasmosis in Mice

\author{
Jingjing Guo ${ }^{1}$, Aihua Zhou ${ }^{2}$, Xiahui Sun ${ }^{1}$, Wenchao Sha ${ }^{1}$, Kang $A i^{1}$, Ge Pan ${ }^{1}$, \\ Chunxue Zhou ${ }^{1}$, Huaiyu Zhou ${ }^{1}$, Hua Cong ${ }^{1 *}$ and Shenyi He ${ }^{\text {1* }}$
}

${ }^{1}$ Department of Parasitology, School of Basic Medical Sciences, Shandong University, Jinan, China, ${ }^{2}$ Department of Pediatrics, Provincial Hospital Affiliated to Shandong University, School of Medicine, Shandong University, Jinan, China

There is no effective protective vaccine against human toxoplasmosis, which is a potential threat to nearly a third of the world population. Vaccines based on virus-like particles (VLPS) have been highly successful in humans for many years, but have rarely been applied against Toxoplasma gondii infection. In this study, we inserted a B cell epitope (SAG1 ${ }_{82-102}$ or SAG1301-320), a $\mathrm{CD}^{+}$cell epitope (HF10 or ROP7), and a CD4 ${ }^{+}$ cell epitope (AS15) of $T$. gondii into a truncated $\mathrm{HBc}_{\Delta}$ (amino acids1-149) particle to construct four chimeric VLP vaccine formulations, i.e., $\mathrm{HBC}_{\Delta \mathrm{H} 82}, \mathrm{HBC}_{\Delta \mathrm{H} 301}, \mathrm{HBC}_{\Delta} \mathrm{R} 82$, and $\mathrm{HBc}_{\Delta \mathrm{R} 301}$. When these chimeric $\mathrm{HBc}$ particles were expressed in Escherichia coli, they showed icosahedral morphology similar to that of the original VLPs and were evaluated as vaccine formulations against acute and chronic toxoplasmosis in a mouse model (BALB/c mice $\left(\mathrm{H}-2^{d}\right)$. All these chimeric HBc VLPs induced strong humoral and cellular immune responses with high lgG antibody titers and interferon(IFN)- $\gamma$ production. Only the mice immunized with $\mathrm{HBc}_{\Delta \mathrm{H} 82}$ showed prolonged survival time (15.6 \pm 3.8 vs. $5.6 \pm 0.8$ days) against acute infection with $\mathrm{RH}$ tachyzoites and decrease in brain parasite load (1,454 \pm 239 vs. 2,091 \pm 263 ) against chronic infection with Prugniuad cysts, as compared to the findings for the control group. These findings suggest that HBc VLPs would act as an effective carrier for delivering effective multiple antigenic epitopes and would be beneficial for developing a safe and long-acting vaccine against toxoplasmosis.

Keywords: Toxoplasma gondii, virus-like particles, $\mathrm{HBc}$, multiple antigenic epitopes, vaccine

\section{INTRODCTION}

Toxoplasma gondii, an obligate intracellular protozoan, is the causative agent of toxoplasmosis. The disease is a severe health threat for fetuses, newborns, and immunocompromised individuals (1). Current treatments cannot completely control this disease because of the ineffectiveness of drugs in killing the latent cyst form of the parasite (2). Developing effective vaccines could help prevent T. gondii infection (3). However, a licensed vaccine for human use is not available. 
Virus-like particles (VLPs) are diverse nanoparticles (size, $20-100 \mathrm{~nm}$ ) that are formed by structural viral proteins, such as capsids, and can self-assemble. They resemble viruses but are noninfectious because they lack viral genetic materials (4, 5). VLPs mimic the 3D conformation of native viruses and display a high density of repetitive effective antigenic epitopes on their surface, which stimulate the desired humoral and cellular responses in humans (6). In recent years, VLPs have provided an excellent option as vectors for producing vaccines against infectious diseases; four VLP vaccines are available commercially (7). However, not much research has been performed on VLP vaccines against $T$. gondii, and more work is required to fill the gaps in this promising field.

Hepatitis B virus (HBV) core antigen $(\mathrm{HBc}$ ) has been extensively used as a VLP platform for many years (6). It is highly expressed in many recombinant gene expression systems, including prokaryotic expression systems, and is easy to selfassemble in vitro (8). It can greatly improve the immunogenicity of foreign antigenic epitopes presented on its surface, especially those inserted into the major immunedominant region (MIR) of the capsid located at the tips of the surface "spikes" (9). Various foreign antigens from bacteria, viruses, and protozoa have been genetically inserted into the particles, and some of these $\mathrm{HBc}$-antigen fusions have reached the clinical testing stage $(6,10)$.

For vaccines to be effective against toxoplasmosis, they should include antigen epitopes that can elicit a protective Th1 immune response, characterized by the generation of long-lived $\mathrm{CD} 8^{+} \mathrm{T}$ cells that can secrete interferon (IFN)- $\gamma$ and develop cytotoxic activity against infected cells (11). $\mathrm{CD}^{+}$cytotoxic T lymphocyte (CTL)-mediated resistance to $T$. gondii cysts in the brain is absolutely correlated with the major histocompatibility complex (MHC) class I $L^{d}$ allele in mice $(12,13)$. The secreted proteins of $T$. gondii, such as dense granules (GRAs) and rhoptry proteins (ROPs), are antigens that are recognized by murine $\mathrm{T}$ lymphocytes and are vaccine candidates against toxoplasmosis (11). The peptide (HPGSVNEFDF) (HF10), derived from GRA6, and the peptide (IPAAAGRFF), derived from ROP7, are the protective immunodominant $L^{d}$-restricted epitopes in mice $(1,14)$. Antibodies also play an important role in host immunity against $T$. gondii; they can directly block tachyzoites and impair their attachment to host cells. SAG1 protein is the major immunogenic surface antigen that is involved in attachment to host cells during $T$. gondii invasion, which makes it a suitable source of $\mathrm{B}$ cell epitopes (15). SAG1 $1_{82-102}$ is a highly immunogenic conformational B cell epitope but was not considered as a vaccine candidate because of the lack of a suitable carrier to maintain the native spatial conformation until date $(16,17) . \mathrm{SAG}_{301-320}$ is a linear B cell epitope that can protect mice against a lethal challenge and is strongly recognized by sera from toxoplasmosis patients $(18,19)$. Moreover, $\mathrm{CD}^{+} \mathrm{T}$ cells constitute an important component of the immune response to T. gondii, and AS15 is a CD4 ${ }^{+} \mathrm{T}$ cell-stimulating peptide that can confer protection against toxoplasmosis (20). Most of these molecules are conserved between type I and type II strains of T. gondii. Although all three strains of the parasite have been isolated from humans, type I and type II strains are more often associated with human disease and the type III strain seems to be more common in animals $(21,22)$.

In this study, we designed four $\mathrm{HBc}$ VLP vaccine formulations, i.e., $\mathrm{HBc}_{\Delta \mathrm{H} 82}, \mathrm{HBc}_{\Delta \mathrm{H} 301}, \mathrm{HBc}_{\Delta \mathrm{R} 82}$, and $\mathrm{HBc}_{\Delta \mathrm{R} 301}$, comprising a $\mathrm{B}$ cell epitope $\left(\mathrm{SAG}_{82-102}\right.$ or $\left.\mathrm{SAG1}_{301-320}\right)$, a $\mathrm{CD}^{+}$cell epitope (HF10 or ROP7), and a CD4 ${ }^{+}$cell epitope (AS15). The efficacy of these vaccines in eliciting humoral and cellular immune responses in BALB/c mice was examined. Immunization of these mice activated $\mathrm{CD} 8^{+} \mathrm{T}$ cells to produce IFN- $\gamma$, activated $B$ cells to produce antibodies, and protected against subsequent challenge with type I and type II strains of T. gondii. Our results indicated that a VLP-based immunization with complex and heterogeneous antigenic epitopes is a promising vaccine approach to protect against toxoplasmosis.

\section{MATERIALS AND METHODS}

\section{Mice}

Female 6-8 week old BALB/c mice $\left(\mathrm{H}-2^{\mathrm{d}}\right)$ were purchased from Shandong University Laboratory Animal Center (Jinan, China). All the mice were bred and maintained in small groups inside separate cages under a 12-h light/dark cycle (lights switched on at 7:00 am). Water and food were available ad libitum to all the mice throughout. The protocol was approved by the Institutional Animal Care and Use Committee of Shandong University (Contract LL201602044). All efforts were made to minimize animal suffering and the number of mice used.

\section{Parasites}

The RH strain, a high-virulence strain of $T$. gondii (type I), was kindly provided by Professor Jilong Shen (Anhui Medical University, Hefei, China). Cultures of RH tachyzoites were propagated in human foreskin fibroblast (HFF) cells in Dulbecco's modified Eagle's medium (DMEM; Sigma-Aldrich, St.Louis, MO) supplemented with 10\% (vol/vol) fetal bovine serum (FBS; Clark Biosciences, Seabrook, MD), as previously described (23). The Prugniuad (Pru) strain, a low-virulence strain of T. gondii (type II), was a kind gift from Professor Xingquan Zhu (Lanzhou Veterinary Research Institute, China). The cysts of the Pru strain were maintained in Kunming mice by oral passage of infectious cysts in the mice, as previously described (24).

\section{Construction of Prokaryotic Expression Plasmids}

When used as a carrier protein to present antigens, $\mathrm{HBc}$ particles have historically been truncated at amino acid 149 to avoid incorporation of host RNA by the C-terminal tail [amino acids (aa) 150-183], which contains the RNA/DNA-binding site of the viral capsid (10). The truncated HBc particles have been represented by $\mathrm{HBc}_{\Delta}$ in this study. A CD8 ${ }^{+}$cell epitope (HF10 or ROP7) and a $\mathrm{B}$ cell epitope $\left(\mathrm{SAG}_{82-102}\right.$ or $\left.\mathrm{SAG} 1_{301-320}\right)$ of T. gondii were inserted between amino acids 78 and 79 of $\mathrm{HBc}_{\Delta}$ particles, with a Gln (Q) and Asp (D) linker at both ends (Figure 1A). A CD4 ${ }^{+}$cell epitope (AS15) was fused into the $\mathrm{C}$ terminal of $\mathrm{HBc}_{\Delta}$ particles. The final constructs were named $\mathrm{HBc}_{\Delta}, \mathrm{HBc}_{\Delta \mathrm{H} 82}, \mathrm{HBc}_{\Delta \mathrm{H} 301}, \mathrm{HBc}_{\Delta \mathrm{R} 82}$ and $\mathrm{HBc}_{\Delta \mathrm{R} 301}$. The amino acid sequences of the inserted $\mathrm{B}, \mathrm{CD} 8^{+}$, and $\mathrm{CD} 4^{+}$cell epitopes 
are provided in Table 1. After addition of a C-terminal His6 tag for purification and $5^{\prime} \mathrm{NdeI}$ and $3^{\prime}$ XhoI overhangs for cloning into the expression plasmid as previously described (25), all the gene segments of the chimeric HBc VLPs were synthesized by Genewiz Biotech Ltd (Suzhou, China) and then cloned into the pET-30a $(+)$ plasmid (Novagen, Madison, WI). Five recombinant plasmids, i.e., pET-30a(+)/HBc $\mathrm{HB}_{\Delta}, \mathrm{HBc}_{\Delta \mathrm{H} 82}$, $\mathrm{HBc}_{\Delta \mathrm{H} 301}, \mathrm{HBc}_{\triangle \mathrm{R} 82}$, and $\mathrm{HBc}_{\Delta \mathrm{R} 301}$, were verified by DNA sequencing. The recombinant plasmid pET-30a(+)/HBc $\mathrm{H}_{\Delta}$ was used as a negative control.

\section{Expression of Chimeric HBc VLPs}

The procedure for expression of the chimeric proteins was performed as previously described (26), with minor modifications. Briefly, Escherichia coli BL21(DE3) (Novagen) cells transformed with the recombinant plasmids, i.e., pET-30a $(+) / \mathrm{HBc}_{\Delta}, \mathrm{HBc}_{\Delta \mathrm{H} 82}, \mathrm{HBc}_{\Delta \mathrm{H} 301}, \mathrm{HBc}_{\Delta \mathrm{R} 82}$, and $\mathrm{HBc}_{\Delta \mathrm{R} 301}$, were grown on Luria-Bertani (LB) agar plates containing kanamycin $(50 \mu \mathrm{g} / \mathrm{ml})$. Individual colonies were cultured at $37^{\circ} \mathrm{C}$ with shaking at $220 \mathrm{rpm}$ in $3 \mathrm{ml} \mathrm{LB}$ medium supplemented with kanamycin $(50 \mu \mathrm{g} / \mathrm{ml})$. On the next day, the night cultures were transferred to $500 \mathrm{ml}$ fresh LB medium with kanamycin for amplification. When the optical density $\left(\mathrm{OD}_{600}\right)$ of the cultures reached 0.6-0.8, expression of the chimeric proteins was induced by adding $0.5 \mathrm{mM}$ isopropyl- $\beta$-D-thiogalactopyranoside(IPTG; Sigma-Aldrich).The cultures were grown for an additional $16-18 \mathrm{~h}$ at $11^{\circ} \mathrm{C}$ and harvested by centrifugation at $4,000 \times \mathrm{g}$ for $20 \mathrm{~min}$ at $4^{\circ} \mathrm{C}$. Resuspended cell pellets were disrupted by sonication, subjected to $12 \%$ sodium dodecyl sulfate (SDS)polyacrylamide gel electrophoresis (PAGE), and stained with Coomassie Blue to analyse chimeric VLPs expression.

\section{Purification of Chimeric HBc VLPs}

The recombinant proteins were purified as described in a previous study (27). The cell pellets of IPTG-induced E. coli transformants were collected and resuspended in lysis buffer (20 mM Tris-HCl, $1 \mathrm{mM}$ phenylmethylsulfonyl fluoride [PMSF], and bacterial protease-inhibitor cocktail, $\mathrm{pH}$ 8.0). These cells were broken up and the chimeric proteins were released by sonication at $400 \mathrm{~W}$ for $4 \mathrm{~s}$, performed at 8 -s intervals for a total of $20 \mathrm{~min}$. Most of the target proteins existed in the form of inclusion bodies in the E. coli expression system. After the inclusion bodies were collected by centrifugation at $10,000 \times \mathrm{g}$ for $20 \mathrm{~min}$ at $4^{\circ} \mathrm{C}$, they were washed three times with wash buffer $(20 \mathrm{mM}$ Tris, $1 \mathrm{mM}$ EDTA, $2 \mathrm{M}$ urea, $1 \mathrm{M}$ $\mathrm{NaCl}, 1 \%$ Triton $\mathrm{X}-100, \mathrm{pH} 8.0$ ) and dissolved in lysis buffer (20 mM Tris, $5 \mathrm{mM}$ DTT, $8 \mathrm{M}$ urea, $\mathrm{pH} 8.0$ ) in a certain ratio overnight. Then, the supernatant was added gradually to the buffer ( $20 \mathrm{mM}$ Tris- $\mathrm{HCl}, 100 \mathrm{mM} \mathrm{NaCl}, \mathrm{pH} 8.0)$, stirred slowly, and gradient-diluted. Then the protein solution was dialyzed against the same buffer overnight in the dialysis bag (Merck Millipore, Billerica, MA). After the supernatant was recovered, His-tagged chimeric HBc VLPs were purified using $\mathrm{Ni}_{2}^{+}$iminodiacetic acid (IDA) affinity chromatography gel (Novagen), following the procedure recommended by the manufacturer.
To identify the chimeric proteins, western blot analyses were performed using an anti-His Tag monoclonal antibody (Abcam, Cambridge, MA), followed by detection with horseradish peroxidase (HRP) Affinipure goat anti-mouse IgG $(\mathrm{H}+\mathrm{L})$ (ZSGB-BIO, Beijing, China). $\mathrm{HBc}_{\Delta}$ protein was used as a negative control in all three experiments. Endotoxin contamination in the chimeric HBc VLPs was analyzed using Limulus amebocyte lysate(LAL) (ZhanJiang A\&C Biological Ltd, Shanghai, China) (28).

Four multiepitope peptides, i.e., H82, H301, R82, and R301, containing a $\mathrm{CD}^{+}$cell epitope (HF10 or ROP7), a B cell epitope $\left(\mathrm{SAG}_{82-102}\right.$ or $\left.\mathrm{SAG} 1_{301-320}\right)$, and a $\mathrm{CD} 4^{+}$cell epitope (AS15) were synthesized (>95\% purity) by Synpeptide Co., Ltd. (Shanghai, China) and stored at $-80^{\circ} \mathrm{C}$ until use.

\section{Electron Microscopy}

The purified chimeric $\mathrm{HBc}$ VLPs, i.e., $\mathrm{HBc}_{\Delta}, \mathrm{HBc}_{\Delta \mathrm{H} 82}$, $\mathrm{HBc}_{\Delta \mathrm{H} 301}, \mathrm{HBc}_{\triangle \mathrm{R} 82}$, and $\mathrm{HBc}_{\triangle \mathrm{R} 301}$, were adsorbed onto carbonformvar-coated copper grids (200 mesh) and negatively stained with $1 \%$ phosphotungstic acid as previously described (29). Three random fields were observed using a transmission electron microscope (TEM; JEM-1011) at an accelerating voltage of 100 $\mathrm{kV}$ with $120,000 \times$ magnification. $\mathrm{HBc}_{\Delta}$ particle was used as a negative control.

\section{Immunization and Challenge in Mice}

The mice were segregated into groups of 23 each and immunized subcutaneously with $50 \mu \mathrm{g}$ of a recombinant protein, i.e., $\mathrm{HBc}_{\Delta}, \mathrm{H} 82, \mathrm{HBc}_{\Delta \mathrm{H} 82}, \mathrm{H} 301, \mathrm{HBc}_{\Delta \mathrm{H} 301}, \mathrm{R} 82, \mathrm{HBc}_{\Delta \mathrm{R} 82}, \mathrm{R} 301$, or $\mathrm{HBc}_{\triangle \mathrm{R} 301}$ ) or $50 \mu \mathrm{l} \mathrm{PBS}$ (blank control) on Days 0 , 14, and 28 as previously described (30). For monitoring of the humoral response, serum samples were collected by retro-orbital bleeding at $0,2,4$, and 6 weeks after the first immunization and were stored at $-80^{\circ} \mathrm{C}$ until analysis. For monitoring of the cellular response, lymphocyte proliferation and cytokine production tests were performed. At 2 weeks after the last immunization, three mice per group were sacrificed and their spleens were obtained (Figure 4A).

To investigate the immune protection of the chimeric $\mathrm{HBc}$ VLPs against acute $T$. gondii infection, 10 mice per group were infected intraperitoneally with a lethal dose $\left(1 \times 10^{3}\right.$ tachyzoites $)$ of the RH strain and were monitored over 20 days as performed previously (58). To evaluate the effect of vaccination in mice with chronic toxoplasmosis, the remaining 10 mice in each group were challenged orally with a sublethal dose (30 cysts) of the Pru strain as previously described (31) (Figure 4A). All the mice were euthanized at 45 days after the challenge and their brains were removed and homogenized in $1 \mathrm{ml}$ PBS. The T. gondii cyst burden in the mouse brains was confirmed by analyzing $10 \mu \mathrm{l}$ samples of each cerebral homogenate with a light microscope as previously described (58).

\section{Evaluation of the Humoral Response}

The T. gondii-specific IgG, IgG1 and IgG2a antibody levels in the serum samples were measured using enzyme-linked immunosorbent assay (ELISA) as previously described (30). Briefly, $50 \mu \mathrm{g}$ of the recombinant proteins, i.e., $\mathrm{HBc}_{\Delta}, \mathrm{H} 82$, 


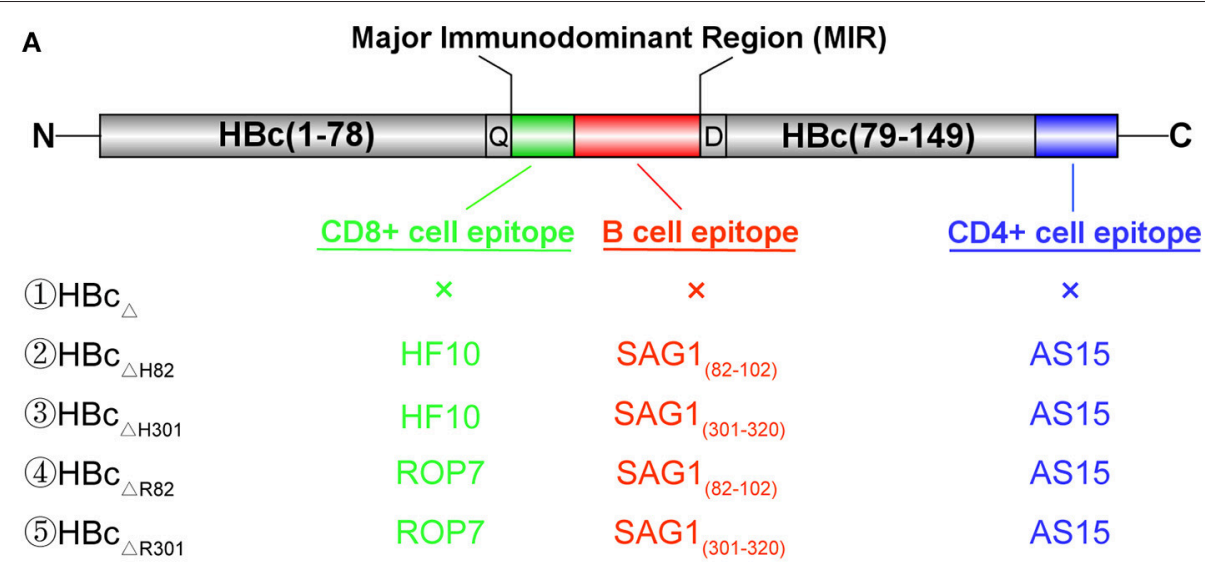

B (a)

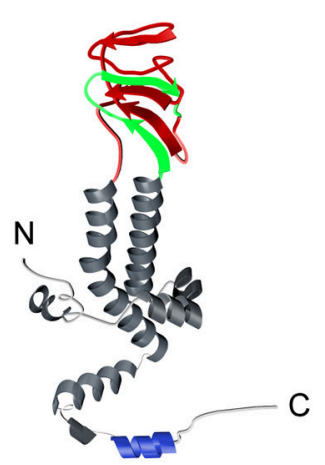

(b)

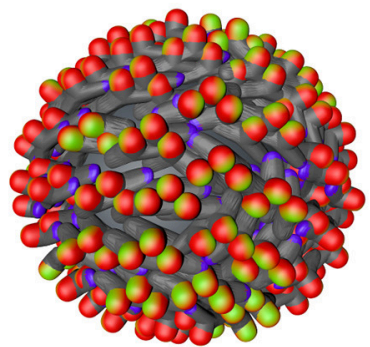

FIGURE 1 | Structure of the chimeric HBc virus-like particles (VLPS). (A) Gene structure of the chimeric HBc VLPS. HBc $\Delta$ represents the truncated HBc particles (aa 1-149). A CD8 ${ }^{+}$T cell epitope (HF10 or ROP7; green) and a B cell epitope (SAG182-102 or SAG1301-320; red) of Toxoplasma gondii were inserted between aa78 and 79 of $\mathrm{HBc}_{\Delta}$ particles (MIR), with a $\mathrm{Gln}(\mathrm{Q})$ and $\mathrm{Asp}(\mathrm{D})$ linker at both ends. Futhermore, a CD4+ cell epitope (AS15) (blue) of T. gondii was fused into the $\mathrm{C}$ terminal of $\mathrm{HBc}_{\Delta}$ particles. (B) The monomer (a) and polymer (b) structures of the chimeric HBc VLPs. The inserted $\mathrm{CD} 8^{+} \mathrm{T}$ cell, $\mathrm{CD} 4^{+} \mathrm{T}$ cell, and B cell epitopes are shown in green, blue, and red, respectively.

TABLE 1 | Identified B cell and T cell epitopes of T. gondii used in this study.

\begin{tabular}{|c|c|c|c|}
\hline Epitope & Type & Conformational/liner & Amino acid sequence \\
\hline 1. SAG1(82-102) & B cell epitope & Conformational & CPKTALTEPPTLAYSPNRQIC \\
\hline 2. SAG1(301-320) & B cell epitope & Liner & FAGAAGSAKSAAGTASHVSI \\
\hline 3. HF10(GRA6) & $\mathrm{CD}^{+}$cell epitope & Liner & HPGSVNEFDF \\
\hline 4. ROP7 & $\mathrm{CD}^{+}$cell epitope & Liner & IPAAAGRFF \\
\hline 5. AS15 & CD4+ ${ }^{+}$cell epitope & Liner & AVEIHRPVPGTAPPS \\
\hline
\end{tabular}

$\mathrm{HBc}_{\Delta \mathrm{H} 82}, \mathrm{H} 301, \mathrm{HBc}_{\Delta \mathrm{H} 301}, \mathrm{R} 82, \mathrm{HBc}_{\Delta \mathrm{R} 82}, \mathrm{R} 301$, and $\mathrm{HBc}_{\Delta \mathrm{R} 301}$, or $50 \mu \mathrm{l}$ PBS (blank control) was adsorbed overnight onto 96-well plates (Corning Incorporated, Corning, NY) at $4{ }^{\circ} \mathrm{C}$ in $50 \mathrm{mM}$ carbonate buffer ( $\mathrm{pH}$ 9.6). After blocking with $1 \%$ low fat milk in phosphate-buffered saline (PBS) containing 0.05\% Tween 20 (PBST) for $1 \mathrm{~h}$ at $37^{\circ} \mathrm{C}$, the mouse serum was diluted in PBS (1:25) and incubated at $37^{\circ} \mathrm{C}$ for $1 \mathrm{~h}$. After washing three times with PBST, the anti-mouse-IgG, IgG1 or IgG2a HRP-conjugated antibodies (Sigma-Aldrich) were added. Peroxidase activity was

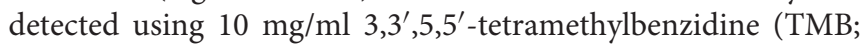
Sigma-Aldrich) and stopped by adding $50 \mu \mathrm{l} 2 \mathrm{M} \mathrm{H}_{2} \mathrm{SO}_{4}$. The results were recorded as the absorbance at $450 \mathrm{~nm}$ and detected with a Thermo Scientific Multiskan (Thermo, Waltham, MA) FC Microplate Photometer. All assays were performed in triplicate.

\section{Evaluation of the Cellular Response}

The percentages of the $\mathrm{CD}^{+}$and $\mathrm{CD}^{+} \mathrm{T}$ lymphocytes subsets of immunized mice were analyzed by flow cytometry as previously described (32). Briefly, 2 weeks after the last immunization, splenocyte suspensions were prepared from three immunized mice per group by pushing the spleens through a wire mesh. After the erythrocytes were lysed, the splenocytes were suspended in Roswell Park Memorial Institute (RPMI)1640 medium supplemented with 10\%FBS. The cells were plated in 96-well plates in triplicate at a density of $2 \times 10^{5}$ cells/well and were stained with anti-mouse CD3-APC (eBiosciences, San Diego, CA), anti- mouse CD4-FITC (eBiosciencesA), and antimouse CD8-PE (eBiosciences) for $30 \mathrm{~min}$ at $4^{\circ} \mathrm{C}$ in the dark. All these cells were analyzed with a Cytoflex S Flow Cytometer 
(Beckman Coulter, USA), and the data were analyzed with the CytExpert software.

To determine the cytokine levels, splenocytes $\left(2 \times 10^{6}\right.$ cells $/ \mathrm{ml}$ ) were stimulated with $10 \mu \mathrm{g} / \mathrm{ml}$ of the recombinant proteins, i.e., $\mathrm{HBc}_{\Delta}, \mathrm{H} 82, \mathrm{HBc}_{\Delta \mathrm{H} 82}, \mathrm{H} 301, \mathrm{HBc}_{\Delta \mathrm{H} 301}, \mathrm{R} 82$, $\mathrm{HBc}_{\triangle \mathrm{R} 82}$, R301, or $\mathrm{HBc}_{\Delta \mathrm{R} 301}$, or $5 \mu \mathrm{g} / \mathrm{ml}$ Con A (SigmaAldrich) (positive control), or $50 \mu \mathrm{l}$ PBS (blank control), as previously described $(33,34)$. The cell-free supernatants from cultured splenocytes were collected and assayed for interleukin (IL)-2 and IL- 4 activities at $24 \mathrm{~h}$, for IL-10 activity at $72 \mathrm{~h}$, and for IFN- $\gamma$ activity at $96 \mathrm{~h}$. The cytokine levels were measured using a commercial ELISA kit (eBioscience) according to the manufacturer's instructions. All assays were performed in triplicate.

\section{STATISTICAL ANALYSIS}

Statistical analysis was performed using SPSS19.0 and GraphPad Prism 7.0. Differences between groups were analyzed using oneway analysis of variance (ANOVA). The survival percentage was analyzed with the Kaplan-Meier test, and survival curves were compared using the log-rank test. Data have been expressed in terms of mean \pm standard deviation (SD) values. Values of $p<$ 0.05 were considered statistically significant.

\section{RESULTS}

\section{Gene Engineering and Chimeric $\mathrm{HBc}$ VLP Production}

The composition of the hybrid $\mathrm{HBc}$ genes, i.e., $\mathrm{HBc}_{\Delta}, \mathrm{HBc}_{\Delta \mathrm{H} 82}$, $\mathrm{HBc}_{\triangle \mathrm{H} 301}, \mathrm{HBc}_{\triangle \mathrm{R} 82}$, and $\mathrm{HBc}_{\triangle \mathrm{R} 301}$, is shown in Figure 1A. Figure 1B shows the expected sites of appearance of these inserted epitopes on the surface of monomer (a) and polymer (b) of HBc VLPs. These genes were inserted into the plasmid pET-30a $(+)$ to construct the recombinant plasmids pET$30 \mathrm{a}(+) / \mathrm{HBc}_{\Delta}, \mathrm{HBc}_{\Delta \mathrm{H} 82}, \mathrm{HBc}_{\Delta \mathrm{H} 301}, \mathrm{HBc}_{\Delta \mathrm{R} 82}$, and $\mathrm{HBc}_{\Delta \mathrm{R} 301}$. After digestion with restriction endonucleases, these plasmids were confirmed by agarose gel electrophoresis. The plasmids of chimeric HBc VLPs $\left(\mathrm{HBc}_{\triangle \mathrm{H} 82}, \mathrm{HBc}_{\triangle \mathrm{H} 301}, \mathrm{HBc}_{\triangle \mathrm{R} 82}, \mathrm{HBc}_{\triangle \mathrm{R} 301}\right)$ were digested into large fragments (4193 bp) and small fragments (2097 bp, 2094 bp, 2094 bp, 2091 bp) by the 5'-ApaI and 3'XhoI endonucleases, respectively, and the non-chimeric $\mathrm{HBc}$ particle $\left(\mathrm{HBc}_{\Delta}\right)$ was $4,193 \mathrm{bp}$ and $1,503 \mathrm{bp}$ correspondingly, which indicated that the recombinant plasmids contained inserts (Figure 2A).

After the chimeric HBc VLPs were expressed in E. coli, they were analyzed by SDS-PAGE and Coomassie Blue staining. Increased expression of the chimeric proteins $\mathrm{HBc}_{\Delta}$ (18.3 $\mathrm{KDa}), \mathrm{HBc}_{\triangle \mathrm{H} 82}(23.2 \mathrm{KD}), \mathrm{HBc}_{\triangle \mathrm{H} 301}(23.0 \mathrm{KDa}), \mathrm{HBc}_{\Delta \mathrm{R} 82}$ $(23.0 \mathrm{KDa})$ and $\mathrm{HBc}_{\triangle \mathrm{R} 301}(22.8 \mathrm{KDa})$ was observed in the supernatants of cellular lysates obtained by sonication (Figure 2B). The chimeric proteins were purified using $\mathrm{Ni}^{+}$ IDA affinity chromatography gels; the purified proteins showed a single band for each preparation with appropriate molecular masses (Figure 2C). These proteins were recognized by a Histag $\mathrm{mAb}$ at the $\mathrm{C}$ terminus of the $\mathrm{HBc}$ particles by western blot analysis (Figure 2D). These results indicated that $\mathrm{HBC}$ VLPs carrying the multiepitopes of $T$. gondii were successfully expressed in a prokaryotic expression system. In addition, the LAL test showed 0.5 endotoxin units $/ \mu \mathrm{g}$ for the chimeric HBc VLPs.

\section{Electron Microscopic Characterization of VLPs}

A truncated version of $\mathrm{HBc}$ (aa 1-149), lacking a protamine-like domain (aa150-183), is known to be sufficient for self-assembly into capsid particles (35). TEM analysis with phosphotungstic acid negative staining showed that multiepitope immunogens of T. gondii-containing truncated $\mathrm{HBc} \operatorname{VLPs}\left(\mathrm{HBc}_{\triangle \mathrm{H} 82}, \mathrm{HBc}_{\triangle \mathrm{H} 301}\right.$, $\mathrm{HBc}_{\triangle \mathrm{R} 82}$, and $\mathrm{HBc}_{\triangle \mathrm{R} 301}$ ) demonstrated good capability for selfassembly and had icosahedral morphology similar to the original corresponding non-chimeric VLPs $\left(\mathrm{HBc}_{\Delta}\right)$ (Figure 3). These particles were homogeneous in size.

\section{Humoral Immune Responses Induced by Vaccination}

To detect the levels of anti-T. gondii antibodies, sera from the immunized mice were tested with ELISA. Total IgG antibodies were detectable as early as 4 weeks after the first vaccination in the mice immunized with $\mathrm{HBc}_{\triangle \mathrm{H} 82}$ and $\mathrm{HBc}_{\triangle \mathrm{R} 82}$ proteins compared with the mice immunized with PBS (Figure 4Ba). These two proteins induced the highest IgG antibody levels 6 weeks after the first vaccination in all vaccinated mice $(p<0.001)$. The IgG antibody levels in the sera of mice immunized with the recombinant proteins containing the SAG1 ${ }_{301-320}$ epitope ( $\mathrm{H} 301, \mathrm{HBc}_{\triangle \mathrm{H} 301}, \mathrm{R} 301$, and $\mathrm{HBc}_{\triangle \mathrm{R} 301}$ ) also increased. In contrast, the mice injected with $\mathrm{HBc}_{\Delta}, \mathrm{H} 82$ and R82 did not have significant antibody titers as compared to those of the control group (PBS).

To determine whether a Th1 and/or a Th2 humoral response was induced by vaccination with the recombinant proteins, the levels of specific IgG1 and IgG2a subclasses were measured. Increased IgG2a production was observed in the sera of mice immunized with $\mathrm{H} 301, \mathrm{HBc}_{\Delta \mathrm{H} 301}, \mathrm{HBc}_{\Delta \mathrm{R} 82}$, R301, and $\mathrm{HBc}_{\triangle \mathrm{R} 301}$ proteins, especially with $\mathrm{HBc}_{\triangle \mathrm{H} 82}(p<0.001$; Figure $4 \mathrm{Bb}$ ) compared with the control group (PBS). Only the mice vaccinated with the $\mathrm{HBc}_{\Delta \mathrm{H} 82}$ protein showed increased IgG1 titers. These results indicated that all the recombinant proteins containing the linear $\mathrm{B}$ cell epitope $\mathrm{SAG1}_{301-320}$, i.e., $\mathrm{H} 301, \mathrm{HBc}_{\triangle \mathrm{H} 301}, \mathrm{R} 301$, and $\mathrm{HBc}_{\triangle \mathrm{R} 301}$, elicited more antiT. gondii antibodies than the control group (PBS) did in the immunized mice. However, for the conformational B cell epitope $\mathrm{SAGl}_{82-102}$, the strong $\operatorname{IgG}$ antibody response was induced only after it was loaded onto the HBc VLP platform $\left(\mathrm{HBc}_{\triangle \mathrm{H} 82}\right.$ and $\left.\mathrm{HBc}_{\triangle \mathrm{R} 82}\right)$ in mice, which can maintain its natural conformation. This specific immune response was of the Th1 type.

\section{Cellular Immune Responses Induced by Vaccination}

After stimulation with $10 \mu \mathrm{g} / \mathrm{ml}$ of the recombinant proteins, i.e., $\mathrm{HBc}_{\Delta}, \mathrm{H} 82, \mathrm{HBc}_{\Delta \mathrm{H} 82}, \mathrm{H} 301, \mathrm{HBc}_{\Delta \mathrm{H} 301}, \mathrm{R} 82, \mathrm{HBc}_{\triangle \mathrm{R} 82}, \mathrm{R} 301$, or 


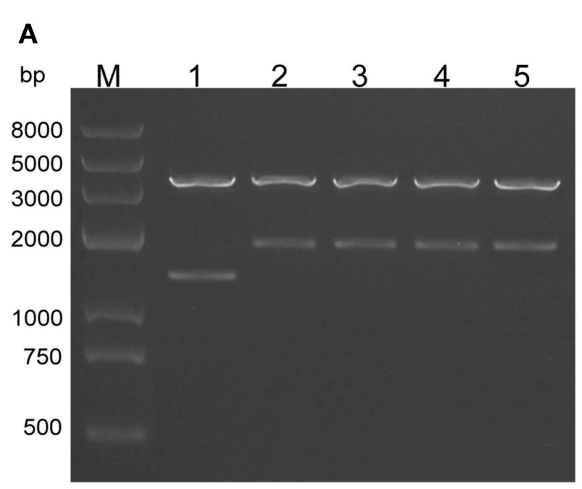

\section{B}

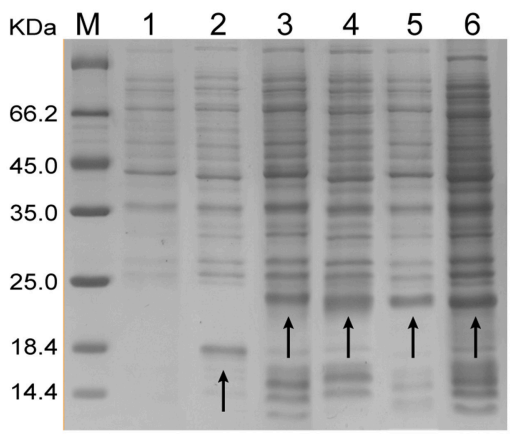

C

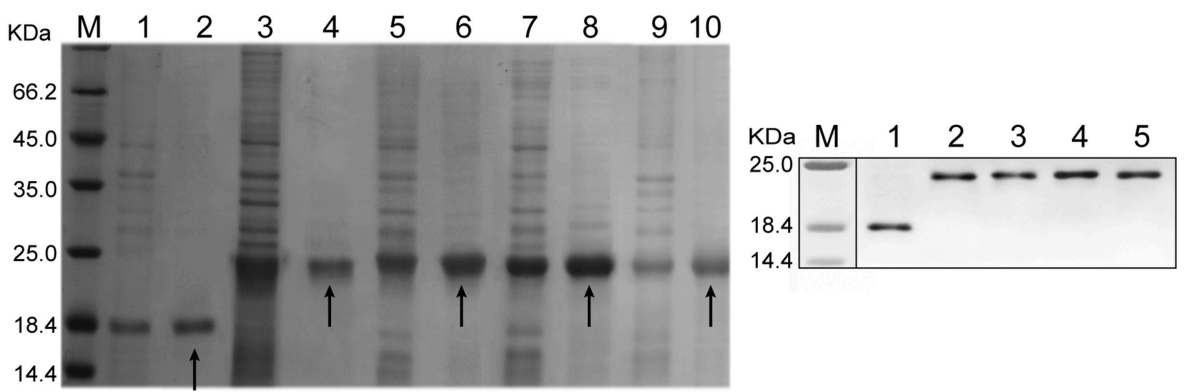

FIGURE 2 | Plasmid identification and protein expression analysis. (A) Five recombinant plasmids, i.e., pET-30a (+) $/ \mathrm{HBc}_{\Delta}, \mathrm{HBc}_{\Delta} \mathrm{H}_{82}, \mathrm{HBc}_{\Delta \mathrm{H} 301}$, HBc $\mathrm{HR}_{\Delta 2}$, and $\mathrm{HBc}_{\triangle \mathrm{R} 301}$, were analyzed by agarose gel electrophoresis. They were digested into large fragments (4,193 bp) and small fragments $(1,503,2,097,2,094,2,094 \mathrm{p}$, and 2,091 bp, respectively) by two endonucleases (5'-Apal and 3'-Xhol, respectively). Lane M: protein marker; Lanes 1-5: recombinant plasmids, i.e., pET-30a (+) /HBc $\mathrm{C}_{\Delta}$, $\mathrm{HBC}_{\triangle \mathrm{H} 82}, \mathrm{HBC}_{\triangle \mathrm{H} 301}, \mathrm{HBc}_{\triangle \mathrm{R} 82}$, and $\mathrm{HBC}_{\triangle \mathrm{R} 301}$. (B) Expression of the chimeric HBc VLPs in Escherichia.coli tested by sodium dodecyl sulfate

(SDS)-polyacrylamide gel electrophoresis (PAGE) and Coomassie Blue staining. Lane M: protein marker; Lane 1: lysates of the pET-30a (+) transformant; Lanes 2-6:

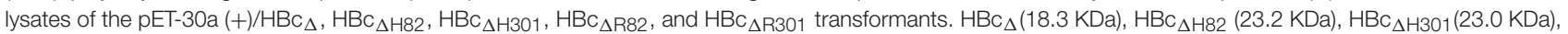
$\mathrm{HBC}_{\triangle \mathrm{R} 82}(23.0 \mathrm{KDa})$, and $\mathrm{HBC}_{\triangle \mathrm{R} 301}(22.8 \mathrm{KDa}$ ) proteins have been indicated by arrows. (C) Purification of the chimeric proteins analyzed by SDS-PAGE and Coomassie Blue staining. The efficiency of the protein purification and molecular mass of the chimeric HBc VLPs were ensured by using the unpurified proteins as

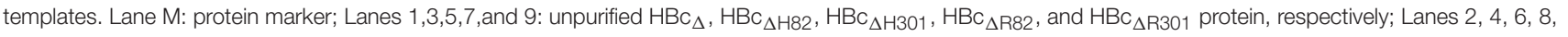
and 10: purified $\mathrm{HBc}_{\Delta}, \mathrm{HBc}_{\Delta \mathrm{H} 82}, \mathrm{HBc}_{\Delta \mathrm{H} 301}, \mathrm{HBc}_{\Delta \mathrm{R} 82}$, and $\mathrm{HBC}_{\Delta \mathrm{R} 301}$ proteins, respectively (indicated by arrows). (D) Western blot analysis of the expressed

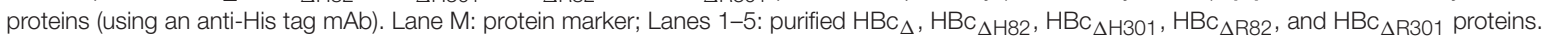

$\mathrm{HBc}_{\triangle \mathrm{R} 301}$, or PBS alone (blank control), the percentages of CD4 ${ }^{+}$ and $\mathrm{CD}^{+} \mathrm{T}$ lymphocytes subsets in the spleens of immunized mice were evaluated by flow cytometry 2 weeks after the third immunization. The percentages of $\mathrm{CD} 4^{+} \mathrm{T}$ cells in all the mice immunized with the recombinant proteins containing the $\mathrm{CD} 4^{+}$ $\mathrm{T}$ cell epitope (AS15) (H82, HBc $\mathrm{H}_{\Delta \mathrm{H} 82}, \mathrm{H} 301, \mathrm{HBc}_{\Delta \mathrm{H} 301}, \mathrm{R} 82$, $\mathrm{HBc}_{\Delta \mathrm{R} 82}, \mathrm{R} 301$, and $\mathrm{HBc}_{\Delta \mathrm{R} 301}$ ), especially the chimeric $\mathrm{HBc}$

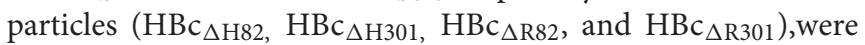
higher than those for the PBS group ( $p<0.01$; Figure 5Aa,b). Apart for the finding for the mice immunized with $\mathrm{HBc}_{\Delta}$ and PBS, the percentages of $\mathrm{CD}^{+} \mathrm{T}$ cells in mice immunized with other recombinant proteins all increased, especially for the chimeric $\mathrm{HBc}$ VLPs containing the HF10 epitope $\left(\mathrm{HBc}_{\triangle \mathrm{H} 82}\right.$ and $\mathrm{HBc}_{\Delta \mathrm{H} 301} ; p<0.001$; Figure 5Aa,c).

Splenocyte supernatants of the immunized mice were harvested at different times after restimulation with the recombinant proteins, conA or PBS to evaluate IL-2, IL-4, IL-10, and IFN- $\gamma$ production by using ELISA. The IFN- $\gamma$ levels in the splenocyte supernatants from the mice immunized with $\mathrm{HBc}_{\Delta \mathrm{H} 82}$ and $\mathrm{HBc}_{\Delta \mathrm{H} 301}(p<0.001), \mathrm{HBc}_{\Delta \mathrm{R} 82}$ and $\mathrm{HBc}_{\Delta \mathrm{R} 301}(p<0.01)$, and with H82, H301, R82, and R301 ( $p$ $<0.05)$ proteins were significantly higher than those of the mice immunized with PBS (Figure 5Ba). The $\mathrm{HBc}_{\Delta \mathrm{H} 82}(p<$ $0.001)$ and $\operatorname{HBc}_{\Delta \mathrm{H} 301}(p<0.01)$ vaccinated mice had higher IL-2 levels than the control group (PBS) did (Figure 5Bb). However, a slight increase in IL-4 and IL-10 production was observed only in the mice immunized with $\mathrm{HBc}_{\Delta \mathrm{H} 82}$ protein compared with those of PBS (Figure 5Bc,d). All these results indicated that the $\mathrm{CD}^{+} \mathrm{T}$ cell epitopes (HF10 and GRA7 $20-28$ ) could both induce robust Th1-type cellular immune responses in mice. When these two peptides were loaded onto the carrier of HBc VLPs, the immune effect was more pronounced, especially for the HF10 peptide $\left(\mathrm{HBc}_{\Delta \mathrm{H} 82}\right.$ and $\left.\mathrm{HBc}_{\Delta \mathrm{H} 301}\right)$. In addition, splenocytes from all groups of mice proliferated to comparable levels in response to ConA (Figure S1). 

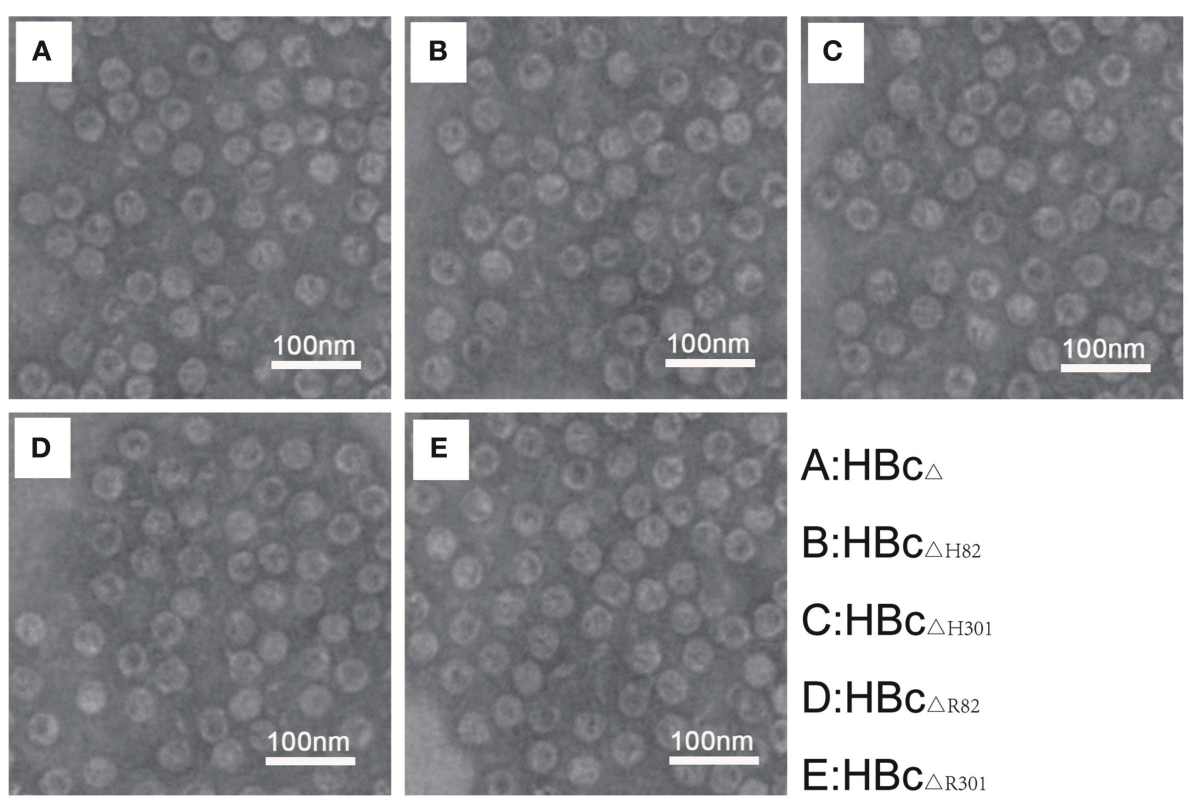

$\mathrm{A}: \mathrm{HBC} \triangle$

$\mathrm{B}: \mathrm{HBC}_{\triangle \mathrm{H} 82}$

$\mathrm{C}: \mathrm{HBc}_{\triangle \mathrm{H} 301}$

$\mathrm{D}: \mathrm{HBC}_{\triangle \mathrm{R} 82}$

$\mathrm{E}: \mathrm{HBC}_{\triangle \mathrm{R} 301}$

FIGURE 3 | Electron microscopic characterization of VLPs. Transmission electron microphotographs of the chimeric $\mathrm{HBc}_{\mathrm{B}} \mathrm{particles}\left[\mathrm{HBc} \mathbf{C}_{\Delta}\right.$ (A), $\mathrm{HBc}_{\Delta \mathrm{H} 82}$ (B),

$\mathrm{HBc}_{\Delta \mathrm{H}_{301}}$ (C), $\mathrm{HBc}_{\Delta \mathrm{R} 82}$ (D), and $\mathrm{HBc}_{\Delta \mathrm{R} 301}$ (E)] showing regular morphology of the VLPs in each preparation. Images were generated using $1 \%$ phosphotungstic acid as a negative stain. Magnification 120, 000x. Scale bar, $100 \mathrm{~nm}$.

\section{Protection Against Acute and Chronic Toxoplasmosis}

To evaluate whether the recombinant proteins could induce effective protection against acute $T$. gondii infection, immunized mice were challenged with $1 \times 10^{3} \mathrm{RH}$ tachyzoites 2 weeks after the final immunization. The survival rates of the challenged mice are shown in Figure 6A. No significant difference was observed among the group immunized with PBS $(5.6 \pm 0.8$ days) and those immunized with the recombinant proteins $\mathrm{HBc}_{\Delta}(5.7 \pm 0.9$ days), H82 (6.1 \pm 1.2 days), H301 (6.0 \pm 1.4 days), $\mathrm{HBc}_{\triangle \mathrm{H} 301}(8.1 \pm 1.5$ days), $\mathrm{R} 82(5.9 \pm 1.2$ days $)$, $\mathrm{HBc}_{\triangle \mathrm{R} 82}\left(8.8 \pm 1.3\right.$ days), $\mathrm{R} 301$ (6.3 \pm 1.1 days), and $\mathrm{HBc}_{\triangle \mathrm{R} 301}$ $(6.6 \pm 1.2$ days). The mice vaccinated with the chimeric $\mathrm{HBc}$ VLPs $\mathrm{HBc}_{\triangle \mathrm{H} 82}(15.6 \pm 3.8$ days $), \mathrm{HBc}_{\triangle \mathrm{H} 301}(8.1 \pm 1.5$ days $)$, $\mathrm{HBc}_{\triangle \mathrm{R} 82}\left(8.8 \pm 1.3\right.$ days), and $\mathrm{HBc}_{\triangle \mathrm{R} 301}(6.6 \pm 1.2$ days $)$ were partially protected compared with the control group (PBS). The longest survival time was observed in the mice immunized with $\mathrm{HBc}_{\Delta \mathrm{H} 82}$ protein, and one mouse even survived after 20 days of challenge.

The resistance provided by this vaccine formulation to $T$. gondii chronic infection was also evaluated by oral challenge the immunized mice with 30 Pru strain cysts. At 45 days after the challenge, the mice vaccinated with $\mathrm{HBc}_{\triangle \mathrm{H} 82}(1454 \pm 239 ; p$ $<0.01)$ and $\mathrm{HBc}_{\triangle \mathrm{H} 301}(1730 \pm 230 ; p<0.05)$ proteins had fewer cysts than the PBS immunized mice did (2091 \pm 263 ; Figure 6B). These results suggested that immunization of the mice with $\mathrm{HBc}_{\triangle \mathrm{H} 82}$, which contained the conformational B cell epitopes (SAG1 $182-102), \mathrm{CD}^{+} \mathrm{T}$ cell epitope (HF10), and CD4 ${ }^{+}$ T cell epitope (AS15), induced substantial resistance to acute and chronic infection with T. gondii.

\section{DISCUSSION}

In this study, we inserted a $\mathrm{B}$ cell epitope $\left(\mathrm{SAG}_{82-102}\right.$ or $\mathrm{SAG}_{301-320}$ ), a CD8 ${ }^{+}$cell epitope (HF10 or ROP7), and a $\mathrm{CD} 4^{+}$ cell epitope (AS15) into truncated $\mathrm{HBc}_{\Delta}$ (aa1-149) to construct four chimeric $\mathrm{HBc}$ VLPs, i.e., $\mathrm{HBc}_{\Delta \mathrm{H} 82}, \mathrm{HBc}_{\Delta \mathrm{H} 301}, \mathrm{HBc}_{\Delta \mathrm{R} 82}$, and $\mathrm{HBC}_{\triangle \mathrm{R} 301}$. When the chimeric $\mathrm{HBc}$ particles were expressed in E. coli, they showed icosahedral morphology similar to that of the original $\mathrm{HBc}$ protein. All these chimeric HBc VLPs induced strong humoral and cellular immune responses, along with high IgG antibody titer and IFN- $\gamma$ production. Prolonged survival time and decreased cyst burden in the brain were observed only in mice vaccinated with the $\mathrm{HBc}_{\Delta \mathrm{H} 82}$ protein.

Hepatitis B virus (HBV) causes both acute and chronic infections of the liver (36). It is a small $42-\mathrm{nm}$ virion carrying a viral DNA genome encapsulated within the HBV core antigen ( $\mathrm{HBcAg})$, which is surrounded by the lipid envelope with embedded HBV surface antigen (HBsAg) (10). HBsAg has been used as a VLP platform, but HBcAg has much higher immunogenicity than the surface antigen as a recombinant protein. It is increasingly being recognized that $\mathrm{HBcAg}$-based VLPs are more efficient and flexible carrier moieties because of various characteristics (37). HBc particles can accommodate foreign antigen epitopes by presented them in three different ways: to the $\mathrm{N}$-terminus or $\mathrm{C}$-terminus, or inserted in the MIR of $\mathrm{HBc}$; all these potential insertion sites could be very resilient in containing over 100 amino acids sequences of antigen without interference with the formation of capsids $(6,10)$. $\mathrm{HBC}$ consists of a protamine-like domain (aa150-183) that is dispensable for particle formation, and it typically contains 


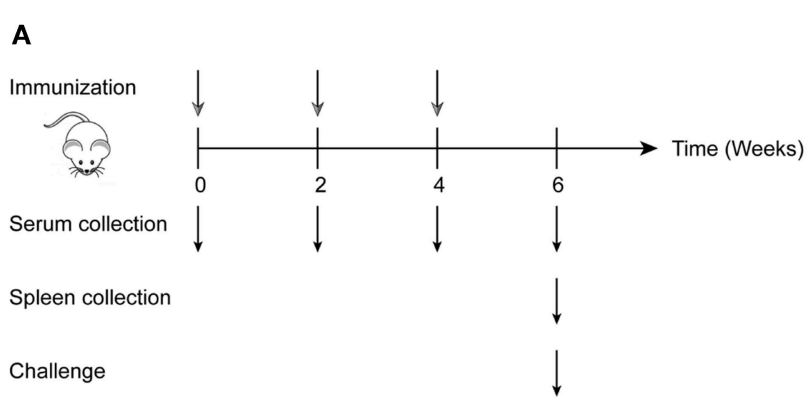

B (a)

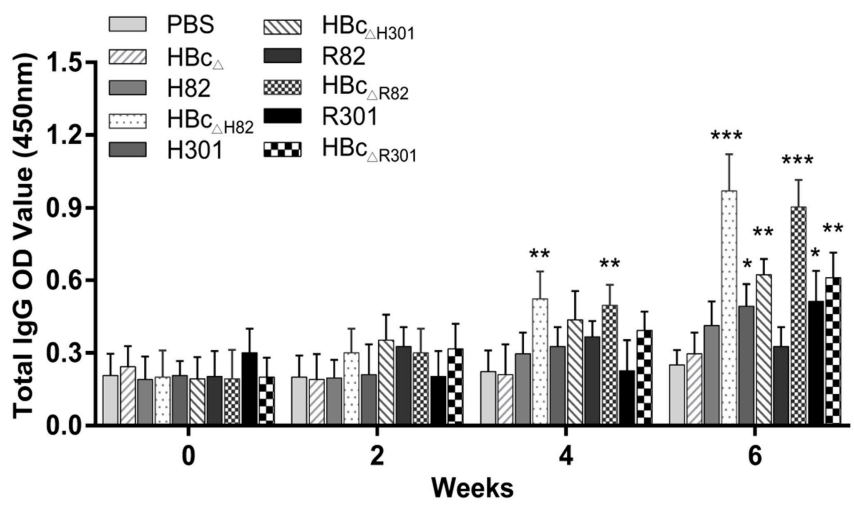

(b)

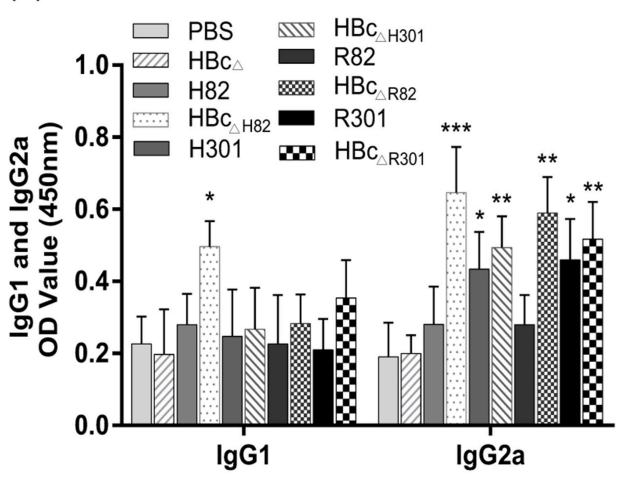

FIGURE 4 | Immunization schedule and humoral immune response induced by vaccination. (A) Schematic diagram of the immunization protocol. BALB/c mice (23 mice/group) were immunized subcutaneously with $50 \mu \mathrm{g}$ of the recombinant proteins $\left(\mathrm{HBc}_{\Delta}, \mathrm{H} 82, \mathrm{HBc} \mathrm{C}_{\Delta} \mathrm{H} 82, \mathrm{H} 301, \mathrm{HBc} \mathrm{C}_{\Delta 301}\right.$, R82, $\mathrm{HBc} \mathrm{C}_{\Delta 82}, \mathrm{R} 301, \mathrm{and}$ $\left.\mathrm{HBc}_{\Delta \mathrm{R} 301}\right)$ at 0,2 , and 4 weeks after first immunization. Serum samples were collected at 0, 2, 4, and 6 weeks. Three mice per group were sacrificed and spleens were obtained 2 weeks after the last immunization. Then, 10 mice per group were infected intraperitoneally with $1 \times 10^{3}$ tachyzoites of the RH strain, and the other 10 mice in each group were orally challenged with 30 cysts of the Pru strain. (B) Detection of the levels of T. gondii-specific IgG antibody (a) and IgG1 and lgG2a subclass antibodies (b) in the sera of the immunized mice by enzyme-linked immunosorbent assay (ELISA). Serum samples were collected from the mice by retro-orbital bleeding at $0,2,4$, and 6 weeks after the first immunization. After stimulation with $10 \mu \mathrm{g} / \mathrm{ml}$ of the recombinant proteins, humoral immune responses were analyzed. Results have been expressed as the mean of $\mathrm{OD}_{450} \pm \mathrm{SD}$ values $(n=15)$ and are representative of at least three independent experiments. ${ }^{\star} p<0.05$, ${ }^{* *} p<0.01,{ }^{* * *} p<0.001$

RNA derived from the production host (e.g., E. coli), which is a dangerous component for vaccines used in humans and animals (9). Therefore, the truncated $\mathrm{HBc}$ (aa1-149) protein is more widely used as a VLP platform. $\mathrm{HBc}$ expressed by E. coli can spontaneously assemble into particles that are of two sizes, one with $\mathrm{T}=3$ icosahedral symmetry (90 dimers) and the other with $\mathrm{T}=4$ symmetry (120 dimers), and have a diameter of approximately $30 \mathrm{~nm}$ or $34 \mathrm{~nm}$, respectively. The truncated $\mathrm{HBC}$ (aa1-149) forms $\sim 95 \%$ of $T=4$ capsids and $\sim 5 \%$ of $T=3$ capsids $(35,38)$. In our study, the truncated $\mathrm{HBc}$ (aa1-149) proteins containing amino acid sequences of antigen epitopes derived from T. gondii $\left(\mathrm{HBc}_{\Delta \mathrm{H} 82}, \mathrm{HBc}_{\Delta \mathrm{H} 301}\right.$, $\mathrm{HBc}_{\triangle \mathrm{R} 82}$, and $\mathrm{HBc}_{\triangle \mathrm{R} 301}$ ) successfully assembled into icosahedral particles and were similar to the original non-chimeric $\mathrm{HBc}$ VLPs $\left(\mathrm{HBc}_{\Delta}\right)$. Most of these particles were uniform in size.

The MIR is located at the tips of the $\alpha$-helical hairpins, which are known as surface-exposed "spikes" (around the codons for Asp78 and Pro79), on the HBc molecule (39). It is a traditionally used site for insertion of foreign epitopes and displays a high density of repetitive exogenous sequences; it is recognized by most of the antibodies induced by $\mathrm{HBc}$ particles to induce strong desirable cellular and humoral immune responses $(30,59)$. The C-terminal insertion (without the terminal protamine-like domain) also appears on the surface of assembled particles and is highly immunogenic (40). Therefore, in the current study, we inserted a $\mathrm{B}$ cell epitope $\left(\mathrm{SAG}_{82-102}\right.$ or $\left.\mathrm{SAG} 1_{301-320}\right)$ and a $\mathrm{CD}^{+}$cell epitope (HF10 or ROP7) in the site between $\mathrm{Asp}^{78}$ and $\mathrm{Pro}^{79}$ and inserted a $\mathrm{CD}^{+}$cell epitope (AS15) into the C-terminus of the truncated $\mathrm{HBc}_{\Delta}(\mathrm{aa1}-149)$ to construct the chimeric $\mathrm{HBc}$ VLPs. The malaria (Plasmodium falciparum) vaccine MalariVax (ICC-1132), produced by Apovia, has a similar foreign insertion site of MIR and the $C$ terminal of $\mathrm{HBc}$ VLP and has already undergone Phase I clinical trials (41). In addition, all the chimeric $\mathrm{HBc}$ particles, i.e., $\mathrm{HBc}_{\Delta \mathrm{H} 82}$, $\mathrm{HBc}_{\Delta \mathrm{H} 301}, \mathrm{HBc}_{\Delta \mathrm{R} 82}$, and $\mathrm{HBc}_{\Delta \mathrm{R} 301}$, induced stronger humoral and cellular immune responses than their corresponding epitope peptide groups, i.e., H82, H301, R82, and R301, in the current study. This finding probably stems from the fact that peptides are extremely susceptible to enzymatic degradation and are poor immunogens on their own (42). HBc-VLP, which act as an excellent delivery system, could effectively protect them 
A (a)
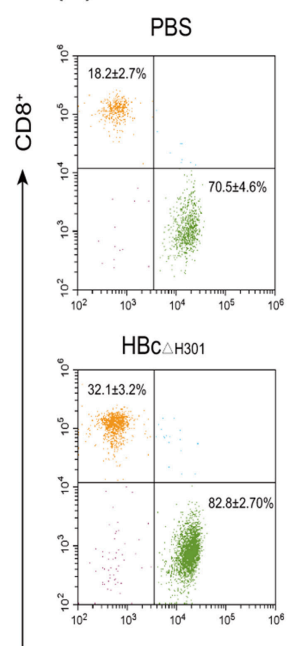

(a)

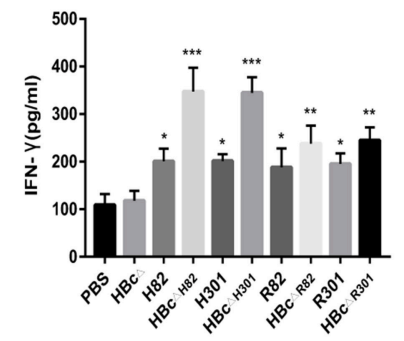

$\mathrm{HBC} \triangle$

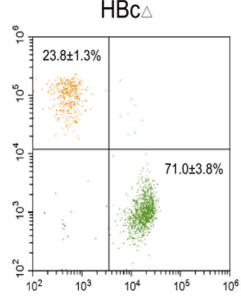

R82

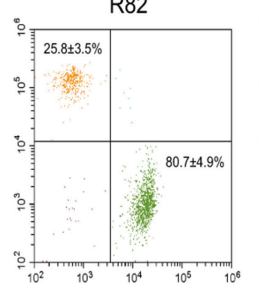

H82

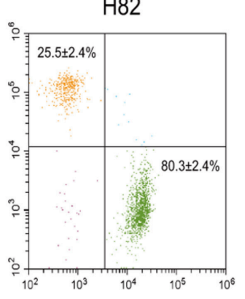

$\mathrm{HBC} \triangle \mathrm{R} 82$

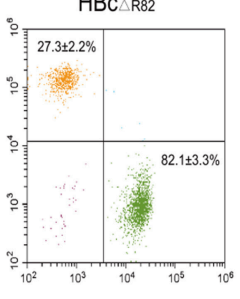

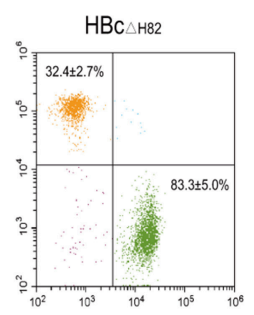

R301

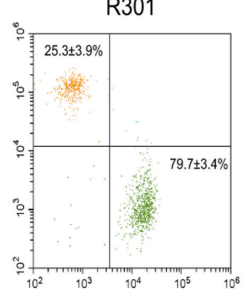

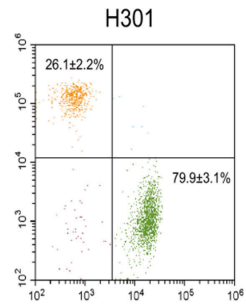

$\mathrm{HBC} \triangle \mathrm{R} 301$

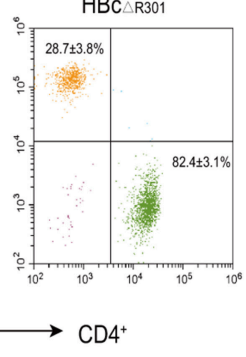

(c)

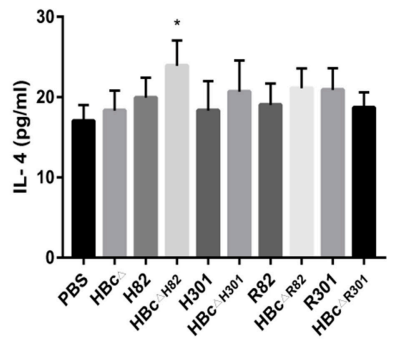

(b)
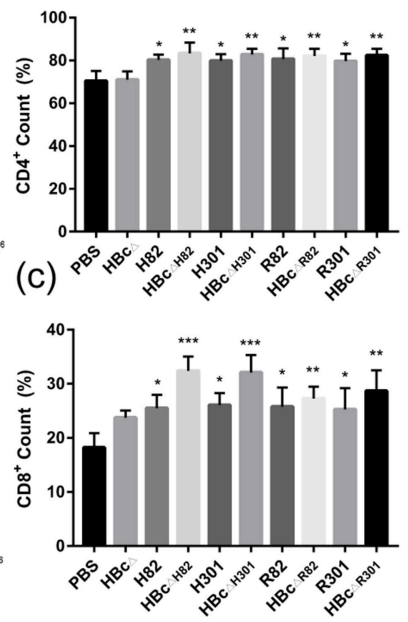

(d)

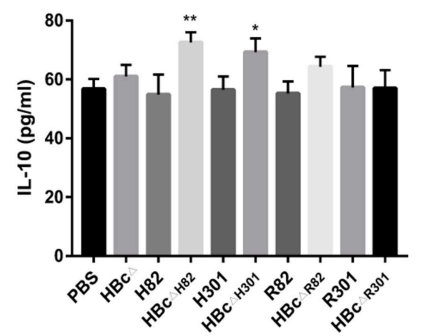

FIGURE 5 | Cellular immune response induced by vaccination. Splenocytes were harvested from three mice per group 2 weeks after the final immunization. After stimulation with $10 \mu \mathrm{g} / \mathrm{ml}$ of the recombinant proteins, i.e., $\mathrm{HBc}_{\Delta}, \mathrm{H} 82, \mathrm{HBc}_{\Delta \mathrm{H} 82}, \mathrm{H} 301, \mathrm{HBc}_{\Delta \mathrm{H} 301}, \mathrm{R}_{82}, \mathrm{HBc} \mathrm{R}_{\Delta 2}$, R301, and HBc $\mathrm{RR}_{301}$, cellular immune responses were analyzed. (A) Percentages of T lymphocyte subsets in the immunized mice. After $72 \mathrm{~h}$ of stimulation, the lymphocytes were stained with anti-mouse CD3-APC, anti-mouse CD4-FITC and anti-mouse CD8-PE and were analyzed by flow cytometry. (B) Cytokine production in the immunized mice. The interleukin (IL)-2 and IL-4 levels in the supernatants of splenocytes at $24 \mathrm{~h}, \mathrm{IL}-10$ levels at $72 \mathrm{~h}$, and interferon (IFN)- $\gamma$ levels at $96 \mathrm{~h}$ were assessed with ELISA. Splenocytes from three mice in each group were tested individually, and the data represent mean \pm SD values. ${ }^{*} p<0.05,{ }^{* *} p<0.01$. ${ }^{\star \star *} p<0.001$
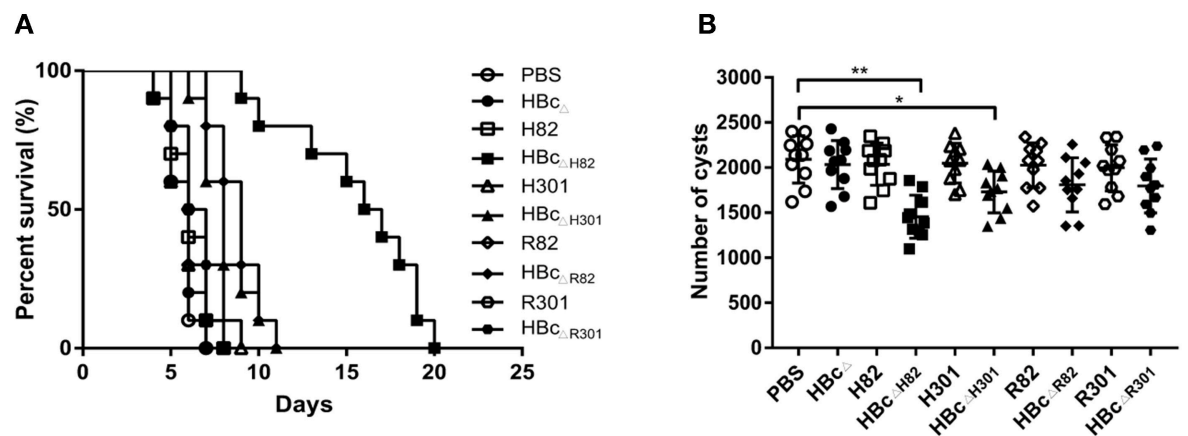

FIGURE 6 | Protective experiments for acute and chronic toxoplasmosis. (A) Survival curve of the immunized mice after lethal challenge. Two weeks after the last immunization, 10 mice per group were intraperitoneally infected with $1 \times 10^{3}$ tachyzoites of the T. gondii RH strain (type I) and observed daily for mortality. (B) Number of cysts in the brain after sublethal challenge. Another 10 mice per group were orally challenged with 30 cysts of the Pru strain (type II). Brain cysts were counted in surviving mice 45 days after the challenge. Data are representative results of three independent experiments and represent mean $\pm \mathrm{SD}$ values. ${ }^{\star} p<0.05$, ${ }^{\star *} p<0.01$. 
from degradation and greatly strengthen their immunogenicity. Furthermore, as a natural antigen, $\mathrm{HBc}$ particles act both as T-helper (Th) cell dependent and Th cell independent antigens, which allows HBc-VLPs to induce a strong adaptive immune response, characterized by high antibody titers and effective T-cell responses (10). To our knowledge, not much research has been performed on a $T$. gondii $\mathrm{HBc}$-VLP vaccine. HBc VLPs are nanoparticles that can pass through tissue barriers and traffic to the lymph nodes more rapidly; they appear to be taken up more efficiently by professional antigen-presenting cells (APCs) (4). Nano-vaccine formulations that assemble GRA7-derived HLA- $B^{\star} 0702$-restricted epitopes into nanospheres (SAPN) and load T. gondii protein extract in porous nanoparticles (DGNP) have been reported; all of these enhanced the immunogenicity of the antigens derived from the parasite $(2,31)$.

Antibodies play an important role in host immunity against T. gondii (43). Antigen-specific antibodies could directly block the tachyzoite in acute toxoplasmosis (44), and B cell-deficient mice are highly likely to develop inflammation in the brain in chronic toxoplasmosis (45). The antibody recognizes the specific part of the antigen, that is, the $\mathrm{B}$ cell epitopes, which are divided into two categories based on their structure and interaction with the antibody: conformational epitopes and linear epitopes (46). In the current study, the conformational B cell epitope (SAG1 $\left.{ }_{82-102}\right)$ peptide (H82 and R82) did not induce higher IgG titers than PBS, but $\left(\mathrm{SAG1}_{82-102}\right)$ did after insertion into the MIR of $\mathrm{HBc}\left(\mathrm{HBc}_{\triangle \mathrm{H} 82}\right.$ and $\left.\mathrm{HBc}_{\triangle \mathrm{R} 82}\right)$. These findings may be attributable to the fact that most $\mathrm{B}$ cell epitopes required to induce the desired humoral immune responses have to maintain their native conformation found in the protein (42); this is enabled by the MIR of $\mathrm{HBc}$, which is composed of two antiparallel helices and forms the spikes of the particle $(10,39)$. In addition, we found that the conformational epitope SAG1 $1_{82-102}$ elicited stronger antibody response than the linear epitope $\mathrm{SAG}_{301-320}$ on the HBc-VLP platform. To our knowledge, conformational B cell epitopes have not been focused on T. gondii vaccine research to date.

Immunity to T. gondii is complex and involves many facets of the immune system. $\mathrm{CD} 4^{+} \mathrm{T}$ lymphocytes play an important role in shaping the immune responses and provide IL-2 for the development of $\mathrm{CD}^{+} \mathrm{T}$ lymphocytes, which can kill $T$. gondii-infected cells in an MHC-restricted, perforin-dependent manner and, more importantly, produce IFN- $\gamma$. IFN- $\gamma$ helps to activate phagocytes to limit the propagation and spreading of the parasite by preventing the growth of tachyzoites and the reactivation of cysts. Therefore, it is critical for controlling both acute and chronic phases of $T$. gondii infection and its level determines the fate of the infection (34, 47-50). Thus, for a vaccine to mimic natural immunity, it should ideally comprise proteins or epitopes that can facilitate MHC class I processing and $\mathrm{CD} 8^{+} \mathrm{T}$ cells development. In the murine model of chronic toxoplasmosis, the resistance mediated by $\mathrm{CD}^{+} \mathrm{T}$ lymphocytes has been definitively mapped to the MHC class I $L^{d}$ allele (11). To our knowledge, however, very few T. gondii specific $L^{d}$-restricted CD8 ${ }^{+} \mathrm{T}$ cell epitopes have been reported to date; of these, only GRA6 (HPGSVNEFDF) (HF10) and ROP7 (IPAAAGRFF) epitopes can elicit robust $\mathrm{T}$ cell responses during the chronic phase $(1,13)$. GRA6 is a dense granule protein and is detected in the parasitophorous vacuole (PV) associated with the membranous network (51). ROP7 is a rhoptry bulb protein and is injected into the host cell cytoplasm relocalizing to the PV membrane, possibly interacting with the host cell cytoplasm (52). It is speculated that these two proteins, after secretion from the apical organelles (dense granules or rhoptries), are proteolytically cleaved into peptides in the proteosome of the infected cells, which are then presented on MHC $L^{d}$ molecules to cytotoxic $\mathrm{CD}^{+}$T cells (13). Consistent with this, the current study showed that HF10 and ROP7 peptides both elicited a potent Th1 immune response, characterized by the activation of $\mathrm{CD} 8^{+} \mathrm{T}$ lymphocytes and increased production of IFN- $\gamma$ and IL-2, especially the HF10 epitope on the $\mathrm{HBc}$ VLP platform $\left(\mathrm{HBc}_{\Delta \mathrm{H} 82}\right.$ and $\left.\mathrm{HBc}_{\Delta \mathrm{H} 301}\right)$. In addition, the peptide AS15, which was presented by the $\mathrm{A}^{\mathrm{b}} \mathrm{MHC}$ class II molecule to the $\mathrm{CD}^{+}{ }^{+} \mathrm{T}$ lymphocytes (20), successfully induced the development of protective $\mathrm{CD} 4^{+} \mathrm{T}$ cells in our study.

Most T. gondii strains can be broadly classified into three clonal lineages, which differ in their virulence. Type I strains (e.g., RH) are highly virulent in mice and are used in survivalbased acute infection models. Low-virulence strains (e.g., type II Pru) have high cyst-forming ability in mice and are used in chronic infection models $(11,53)$. The survival rate and brain cyst burden of immunized mice are considered direct approaches for evaluating the protective efficacy of a candidate vaccine against acute and chronic toxoplasmosis $(45,54)$. In the current study, the mice immunized with $\mathrm{HBc}_{\Delta \mathrm{H} 82}$ showed prolonged survival time and lesser brain cysts than mice immunized with PBS. These results are consistent with the above findings that only the mice immunized with $\mathrm{HBc}_{\Delta \mathrm{H} 82}$ successfully triggered both strong humoral and cellular immune responses in all the vaccinated mice, and these two immune responses were interrelated and acted synergistically to increase protection against acute and chronic infection with $T$. gondii (49). Increased production of the cytokines IL-10 and IL-4, apart from IFN- $\gamma$ and IL-2, may also be helpful against acute toxoplasmosis in immunized mice, because they can reduce short-term fatality by decreasing excessive and lethal Th1-type responses at the early acute stage of the disease $(32,55)$. A possible explanation is the activation of $\mathrm{CD}^{+} \mathrm{T}$ cells induced by AS15. Although most of them differentiate into Th1 cells triggered by IFN- $\gamma$ secreted from the activated $\mathrm{CD} 8^{+}$ $\mathrm{T}$ cells, a small number of $\mathrm{CD} 4^{+} \mathrm{T}$ cells still differentiate into TH2 cells, resulting in a slight but significant increase in IL10 and IL-4 secretion. Similar activation of a T helper immune response with high levels of Th1 and low levels of Th2 related cytokines has been elicited by many other promising $T$. gondii vaccines also $(33,56,57)$. In addition, decrease in the number of brain cysts was also observed in mice after vaccination with $\mathrm{HBc}_{\Delta \mathrm{H} 301}$ protein, which contains the same peptide $\mathrm{HF} 10$ as $\mathrm{HBc}_{\triangle \mathrm{H} 82}$. This may indicate that the useful features of HF10, as an immunodominant $L^{d}$ gene restricted epitope whose region was found to control cyst formation, can be utilized well on this VLP carrier platform. Immunization of $L^{d}$ mice with an HF10-containing vaccine comprising palmitic acid moieties or a monophosphoryl lipid A derivative was found to induce potent IFN- $\gamma$ production from $L^{d}$-restricted $\mathrm{CD}^{+} \mathrm{T}$ cells and protect mice from Pru strain challenge (11).

In conclusion, the $\mathrm{HBC}$ VLPs displayed a high density of effective antigenic epitopes of $T$. gondii on their surface 
and elicited potent humoral and cellular responses. The mice vaccinated with the $\mathrm{HBc}_{\Delta \mathrm{H} 82}$ formulation survived after lethal and sublethal doses of parasite challenge. To our knowledge, no VLP vaccine against $T$. gondii that simultaneously contains a conformational $\mathrm{B}$ epitope, an $L^{d}$-restricted $\mathrm{CD}^{+}$ $\mathrm{T}$ cell epitope, and an $A^{b}$-restricted $\mathrm{CD}^{+} \mathrm{T}$ cell epitope has been reported yet. Our study provides a novel and efficient strategy to develop vaccines against infection with this parasite. However, the significant differences between mice and humans, including those in MHC molecules, should not be ignored. Therefore, finding proteins or epitopes that are immunogenic and protective to the human body is an important topic for future research on vaccines against $T$. gondii; this also requires in-depth understanding of the molecular mechanisms governing the activation of the immune system in humans.

\section{AUTHOR CONTRIBUTIONS}

JG, SH, and HC designed experiments. JG, XS, and WS performed experiments and analyzed data. JG wrote the

\section{REFERENCES}

1. Frickel EM, Sahoo N, Hopp J, Gubbels MJ, Craver MP, Knoll LJ, et al. Parasite stage-specific recognition of endogenous Toxoplasma gondii-derived CD8+ T cell epitopes. J Infect Dis. (2008) 198:1625-33. doi: 10.1086/593019

2. El BK, Zhou Y, Dasgupta D, Cobb D, Dubey JP, Burkhard P, et al. Effectiveness of a novel immunogenic nanoparticle platform for Toxoplasma peptide vaccine in HLA transgenic mice. Vaccine. (2014) 32:3243-8. doi: 10.1016/j.vaccine.2014.03.092

3. Innes EA. Vaccination against Toxoplasma gondii: an increasing priority for collaborative research. Expert Rev Vaccines. (2010) 9:1117-9. doi: 10.1586/erv.10.113

4. Smith DM, Simon JK, Baker JR. Applications of nanotechnology for immunology. Nat Rev Immunol. (2013) 13:592-605. doi: 10.1038/nri3488

5. Smith JD, Morton LD, Ulery BD. Nanoparticles as synthetic vaccines. Curr Opin Biotechnol. (2015) 34:217-24. doi: 10.1016/j.copbio.2015.03.014

6. Rodríguez-Limas WA, Sekar K, Tyo KE. Virus-like particles: the future of microbial factories and cell-free systems as platforms for vaccine development. Curr Opin Biotechnol. (2013) 24:1089-93. doi: 10.1016/j.copbio.2013.02.008

7. Kushnir N, Streatfield SJ, Yusibov V. Virus-like particles as a highly efficient vaccine platform: diversity of targets and production systems and advances in clinical development. Vaccine. (2012) 31:58-83. doi: $10.1016 /$ j.vaccine.2012.10.083

8. Bellier B, Klatzmann D. Virus-like particle-based vaccines against hepatitis $C$ virus infection. Expert Rev Vaccines. (2013) 12:143-54. doi: 10.1586/erv.13.10

9. Geldmacher A, Skrastina D, Petrovskis I, Borisova G, Berriman JA, Roseman $\mathrm{AM}$, et al. An amino-terminal segment of hantavirus nucleocapsid protein presented on hepatitis B virus core particles induces a strong and highly cross-reactive antibody response in mice. Virology. (2004) 323:108-19. doi: 10.1016/j.virol.2004.02.022

10. Roose K, De Baets S, Schepens B, Saelens X. Hepatitis B core-based viruslike particles to present heterologous epitopes. Expert Rev Vaccines. (2013) 12:183-98. doi: 10.1586/erv.12.150

11. Tan TG, Mui E, Cong H, Witola WH, Montpetit A, Muench SP, et al. Identification of T. gondii epitopes, adjuvants, and host genetic factors that influence protection of mice and humans. Vaccine. (2010) 28:3977-89. doi: $10.1016 /$ j.vaccine.2010.03.028 manuscript. AZ, HC, and $\mathrm{CZ}$ revised the manuscript. KA, GP, and $\mathrm{HZ}$ provided advice for experiment. All authors read and approved the final manuscript.

\section{FUNDING}

This study was supported by grants from Shandong Natural Science Foundation Project (Grant No. ZR2016HM74 and ZR2017MH043), the National Natural Science Foundation Project of China (Grant No. 81071373, 81271857 and 81171604), and the development Project of Shandong Province (Grant No. 2016GSF201201).

\section{SUPPLEMENTARY MATERIAL}

The Supplementary Material for this article can be found online at: https://www.frontiersin.org/articles/10.3389/fimmu. 2019.00592/full\#supplementary-material

Figure S1 | The production of cytokines in the immunized mice stimulated with ConA (positive control) at different times. The levels of IFN- $\gamma$ (A), IL-2 (B), IL-4 (C), and IL-10 (D) in the supernatants of splenocytes were assessed by ELISA.

12. Brown CR, Hunter CA, Estes RG, Beckmann E, Forman J, David C, et al. Definitive identification of a gene that confers resistance against Toxoplasma cyst burden and encephalitis. Immunology. (1995) 85:419-28.

13. Henriquez FL, Woods S, Cong H, McLeod R, Roberts CW. Immunogenetics of Toxoplasma gondii informs vaccine design. Trends Parasitol. (2010) 26:550-5. doi: 10.1016/j.pt.2010.06.004

14. Blanchard N, Gonzalez F, Schaeffer M, Joncker NT, Cheng T, Shastri AJ, et al. Immunodominant, protective response to the parasite Toxoplasma gondii requires antigen processing in the endoplasmic reticulum. Nat Immunol. (2008) 9:937-44. doi: 10.1038/ni.1629

15. Velge-Roussel F, Dimier-Poisson I, Buzoni-Gatel D, Bout D. AntiSAG1 peptide antibodies inhibit the penetration of Toxoplasma gondii tachyzoites into enterocyte cell lines. Parasitology. (2001) 123:225-33. doi: $10.1017 /$ S0031182001008460

16. Godard I, Estaquier J, Zenner L, Bossus M, Auriault C, Darcy F, et al. Antigenicity and immunogenicity of P30-derived peptides in experimental models of toxoplasmosis. Mol Immunol. (1994) 31:1353-63.

17. Graille M, Stura EA, Bossus M, Muller BH, Letourneur O, Battail-Poirot $\mathrm{N}$, et al. Crystal structure of the complex between the monomeric form of Toxoplasma gondii surface antigen 1 (SAG1) and a monoclonal antibody that mimics the human immune response. J Mol Biol. (2005) 354:447-58. doi: 10.1016/j.jmb.2005.09.028

18. Siachoque H, Guzman F, Burgos J, Patarroyo ME, Gomez MJE. Toxoplasma gondii: immunogenicity and protection by P30 peptides in a murine model. Exp Parasitol. (2006) 114:62-5. doi: 10.1016/j.exppara.2006.02.005

19. Cardona N, de-la-Torre A, Siachoque H, Patarroyo MA, GomezMarin JE. Toxoplasma gondii: P30 peptides recognition pattern in human toxoplasmosis. Exp. Parasitol. (2009) 123:199-202. doi: 10.1016/j.exppara.2009.06.017

20. Grover HS, Blanchard N, Gonzalez F, Chan S, Robey EA, Shastri N. The Toxoplasma gondii peptide AS15 elicits CD4 T cells that can control parasite burden. Infect Immun. (2012) 80:3279-88. doi: 10.1128/IAI.00425-12

21. Howe DK, Sibley LD. Toxoplasma gondii comprises three clonal lineages: correlation of parasite genotype with human disease. I Infect Dis. (1995) 172:1561-6.

22. Melo MB, Jensen KD, Saeij JP. Toxoplasma gondii effectors are master regulators of the inflammatory response. Trends Parasitol. (2011) 27:487-95. doi: 10.1016/j.pt.2011.08.001 
23. Shen B, Sibley LD. Toxoplasma aldolase is required for metabolism but dispensable for host-cell invasion. Proc Natl Acad Sci U S A. (2014) 111:356772 .

24. Zhou CX, Zhou DH, Elsheikha HM, Zhao Y, Suo X, Zhu XQ. Metabolomic profiling of mice serum during toxoplasmosis progression using liquid chromatography-mass spectrometry. Sci Rep. (2016) 6:19557. doi: $10.1038 /$ srep 19557

25. Sockolosky JT, Szoka FC. Periplasmic production via the pET expression system of soluble, bioactive human growth hormone. Protein Expr Purif. (2013) 87:129-35. doi: 10.1016/j.pep.2012.11.002

26. Lin CJ, Chen NY, Chen JB, Lu CS, Hung AF, Shiung YY, et al. $\mathrm{C} \varepsilon \mathrm{mX}$ peptide-carrying $\mathrm{HBcAg}$ virus-like particles induced antibodies that down-regulate mIgE-B lymphocytes. Mol Immunol. (2012) 52:190-9. doi: 10.1016/j.molimm.2012.05.015

27. Bin MSIF, Garcia-Maya M, Brown P, Bui T, Nishimura Y, Palermo AR, et al. Yield optimisation of Hepatitis B virus core particles in E. coli expression system for drug delivery applications. Sci Rep. (2017) 7:43160. doi: $10.1038 /$ srep43160

28. Qian L, Chen W, Wang S, Liu Y, Jia X, Fu Y, et al. Immune complex negatively regulates toll-like receptor 3-triggered tumour necrosis factor $\alpha$ production in B cells. Cent Eur J Immunol. (2017) 42:223-30. doi: 10.5114/ceji.2017. 70962

29. Newman M, Suk FM, Cajimat M, Chua PK, Shih C. Stability and morphology comparisons of self-assembled virus-like particles from wild-type and mutant human hepatitis B virus capsid proteins. J Virol. (2003) 77:12950-60. doi: 10.1128/JVI.77.24.12950-12960.2003

30. Skrastina D, Bulavaite A, Sominskaya I, Kovalevska L, Ose V, Priede $\mathrm{D}$, et al. High immunogenicity of a hydrophilic component of the hepatitis B virus preS1 sequence exposed on the surface of three viruslike particle carriers. Vaccine. (2008) 26:1972-81. doi: 10.1016/j.vaccine.2008. 02.030

31. Dimier-Poisson I, Carpentier R, N'Guyen TT, Dahmani F, Ducournau C, Betbeder D. Porous nanoparticles as delivery system of complex antigens for an effective vaccine against acute and chronic Toxoplasma gondii infection. Biomaterials. (2015) 50:164-75. doi: 10.1016/j.biomaterials.2015. 01.056

32. Guo J, Sun X, Yin H, Wang T, Li Y, Zhou C, et al. Chitosan microsphere used as an effective system to deliver a linked antigenic peptides vaccine protect mice against acute and chronic toxoplasmosis. Front Cell Infect Microbiol. (2018) 8:163. doi: $10.3389 /$ fcimb.2018.00163

33. Cui X, Lei T, Yang D, Hao P, Li B, Liu Q. Toxoplasma gondii immune mapped protein-1 (TgIMP1) is a novel vaccine candidate against toxoplasmosis. Vaccine. (2012) 30:2282-7. doi: 10.1016/j.vaccine.2012.01.073

34. Zheng B, Lu S, Tong Q, Kong Q, Lou D. The virulence-related rhoptry protein 5 (ROP5) of Toxoplasma Gondii is a novel vaccine candidate against toxoplasmosis in mice. Vaccine. (2013) 31:4578-84. doi: 10.1016/j.vaccine.2013.07.058

35. Zlotnick A, Cheng N, Conway JF, Booy FP, Steven AC, Stahl SJ, et al. Dimorphism of hepatitis B virus capsids is strongly influenced by the C-terminus of the capsid protein. Biochemistry. (1996) 35:7412-21. doi: 10.1021/bi9604800

36. Seeger C, Mason WS. Hepatitis B virus biology. Microbiol Mol Biol Rev. (2000) 64:51-68. doi: 10.1128/mmbr.64.1.51-68.2000

37. Whitacre DC, Lee BO, Milich DR. Use of hepadnavirus core proteins as vaccine platforms. Expert Rev Vaccines. (2009) 8:1565-73. doi: 10.1586/erv.09.121

38. Dryden KA, Wieland SF, Whitten-Bauer C, Gerin JL, Chisari FV, Yeager M. Native hepatitis B virions and capsids visualized by electron cryomicroscopy. Mol Cell. (2006) 22:843-50. doi: 10.1016/j.molcel.2006. 04.025

39. Ravin NV, Blokhina EA, Kuprianov VV, Stepanova LA, Shaldjan AA, Kovaleva $\mathrm{AA}$, et al. Development of a candidate influenza vaccine based on viruslike particles displaying influenza M2e peptide into the immunodominant loop region of hepatitis B core antigen: Insertion of multiple copies of M2e increases immunogenicity and protective efficiency. Vaccine. (2015) 33:33927. doi: 10.1016/j.vaccine.2015.04.066

40. Peyret H, Gehin A, Thuenemann EC, Blond D, El TA, Beales L, et al. Tandem fusion of hepatitis B core antigen allows assembly of virus-like particles in bacteria and plants with enhanced capacity to accommodate foreign proteins. PLoS ONE. (2015) 10:e0 120751. doi: 10.1371/journal.pone.0120751

41. Yin Y, Zhang S, Cai C, Zhang J, Dong D, Guo Q, et al. Deletion modification enhances anthrax specific immunity and protective efficacy of a hepatitis B core particle-based anthrax epitope vaccine. Immunobiology. (2014) 219:97-103. doi: 10.1016/j.imbio.2013.0 8.008

42. Skwarczynski M, Toth I. Peptide-based synthetic vaccines. Chem Sci. (2016) 7:842-54. doi: 10.1039/c5sc03892h

43. Correa D, Cañedo-Solares I, Ortiz-Alegría LB, Caballero-Ortega $H$, Rico-Torres CP. Congenital and acquired toxoplasmosis: diversity and role of antibodies in different compartments of the host. Parasite Immunol. (2007) 29:651-60. doi: 10.1111/j.1365-3024.2007. 00982.x

44. Sayles PC, Gibson GW, Johnson LL. B cells are essential for vaccinationinduced resistance to virulent Toxoplasma gondii. Infect Immun. (2000) 68:1026-33. doi: 10.1128/IAI.68.3.1026-1033.2000

45. Zheng B, Ding J, Chen X, Yu H, Lou D, Tong Q, et al. Immuno-Efficacy of a $T$. gondii secreted protein with an altered thrombospondin repeat (TgSPATR) As a Novel DNA Vaccine Candidate against Acute Toxoplasmosis in BALB/c Mice. Front Microbiol. (2017) 8:216. doi: 10.3389/fmicb.2017. 00216

46. Zhang W, Niu Y, Xiong Y, Ke M. Prediction of conformational B-cell epitopes. Methods Mol Biol. (2014) 1184:185-96. doi: 10.1007/978-1-4939-11 15-8_10

47. Denkers EY, Gazzinelli RT. Regulation and function of T-cell-mediated immunity during Toxoplasma gondii infection. Clin Microbiol Rev. (1998) 11:569-88.

48. Filisetti D, Candolfi E. Immune response to Toxoplasma gondii. Ann Ist Super Sanita. (2004) 40:71-80. doi: 10.1093/intimm/dxy004

49. Ching XT, Fong MY, Lau YL. Evaluation of immunoprotection conferred by the subunit vaccines of GRA2 and GRA5 against acute toxoplasmosis in BALB/c Mice. Front Microbiol. (2016) 7:609. doi: 10.3389/fmicb.2016. 00609

50. Sonaimuthu P, Ching XT, Fong MY, Kalyanasundaram R, Lau YL. Induction of protective immunity against toxoplasmosis in BALB/c mice vaccinated with Toxoplasma gondii Rhoptry-1. Front Microbiol. (2016) 7:808. doi: $10.3389 /$ fmicb. 2016.00808

51. Lecordier L, Moleon-Borodowsky I, Dubremetz JF, Tourvieille B, Mercier C, Deslée D, et al. Characterization of a dense granule antigen of Toxoplasma gondii (GRA6) associated to the network of the parasitophorous vacuole. $\mathrm{Mol}$ Biochem Parasitol. (1995) 70:85-94.

52. Hajj HE, Lebrun M, Fourmaux MN, Vial H, Dubremetz JF. Characterization, biosynthesis and fate of ROP7, a ROP2 related rhoptry protein of Toxoplasma gondii. Mol Biochem Parasitol. (2006) 146:98-100. doi: 10.1016/j.molbiopara.2005.10.011

53. Soête M, Camus D, Dubremetz JF. Experimental induction of bradyzoitespecific antigen expression and cyst formation by the RH strain of Toxoplasma gondii in vitro. Exp Parasitol. (1994) 78:361-70.

54. Luo F, Zheng L, Hu Y, Liu S, Wang Y, Xiong Z, et al. Induction of Protective Immunity against Toxoplasma gondii in mice by nucleoside triphosphate hydrolase-II (NTPase-II) Self-amplifying RNA vaccine encapsulated in lipid nanoparticle (LNP). Front Microbiol. (2017) 8:605. doi: $10.3389 /$ fmicb.2017.00605

55. Gazzinelli RT, Wysocka M, Hieny S, Scharton-Kersten T, Cheever A, Kühn $\mathrm{R}$, et al. In the absence of endogenous IL-10, mice acutely infected with Toxoplasma gondii succumb to a lethal immune response dependent on $\mathrm{CD} 4+\mathrm{T}$ cells and accompanied by overproduction of IL-12, IFN-gamma and TNF-alpha. J Immunol. (1996) 157:798-805.

56. Desolme B, Mévélec MN, Buzoni-Gatel D, Bout D. Induction of protective immunity against toxoplasmosis in mice by DNA immunization with a plasmid encoding Toxoplasma gondii GRA4 gene. Vaccine. (2000) 18:2512-21. doi: 10.1016/s0264-410x(00)00035-9

57. Chen J, Li ZY, Huang SY, Petersen E, Song HQ, Zhou DH, et al. Protective efficacy of Toxoplasma gondii calcium-dependent protein kinase 1 (TgCDPK1) adjuvated with recombinant IL-15 and IL-21 against 
experimental toxoplasmosis in mice. BMC Infect Dis. (2014) 14:487. doi: 10.1186/1471-2334-14-487

58. Wang JL, Elsheikha HM, Zhu WN, Chen K, Li TT, Yue DM, et al. Immunization with Toxoplasma gondii GRA17 deletion mutant induces partial protection and survival in challenged mice. Front Immunol. (2017) 8:730. doi: 10.3389/fimmu.2017.00730

59. Wang W, Feng F, Lv J, Xie Z, Chen J, Zhang L, et al. Major immunodominant region of Hepatitis B virus core antigen as a delivery vector to improve the immunogenicity of the fusion antigen ROP2-SAG1 multiepitope from Toxoplasma gondii in Mice. Viral Immunol. (2017) 30:50815. doi: $10.1089 /$ vim.2016.0135
Conflict of Interest Statement: The authors declare that the research was conducted in the absence of any commercial or financial relationships that could be construed as a potential conflict of interest.

Copyright (c) 2019 Guo, Zhou, Sun, Sha, Ai, Pan, Zhou, Zhou, Cong and He. This is an open-access article distributed under the terms of the Creative Commons Attribution License (CC BY). The use, distribution or reproduction in other forums is permitted, provided the original author(s) and the copyright owner(s) are credited and that the original publication in this journal is cited, in accordance with accepted academic practice. No use, distribution or reproduction is permitted which does not comply with these terms. 